\title{
How Immunoprotein Diagnostic Testing Has Become Beneficial to Human Body
}

\author{
Ashish Gujrathi \\ SEO Analyst at Allied Market Research, Maharashtra, India.
}

Correspondence Author: Ashish Gujrathi, SEO Analyst at Allied Market Research, Maharashtra, India.

Received date: April 05, 2021; Accepted date: April 27, 2021; Published date: May 08, 2021

Citation: Gujrathi A. (2021) How Immunoprotein Diagnostic Testing Has Become Beneficial to Human Body. Clinical Medical Reviews and Reports 3(5); DOI:10.31579/2690-8794/080

Copyright: () 2021 Ashish Gujrathi, This is an open access article distributed under the Creative Commons Attribution License, which permits unrestricted use, distribution, and reproduction in any medium, provided the original work is properly cited.

Immunoproteins can be defined as proteins used as a bag for immunological probes or therapies. Immunoprotein diagnostic testing is regarded as the process of analyzing and identifying the level of immunoproteins in the body for the examination of diseases in regards to specific proteins, for example pre-albumin, immunoglobulin, and others.

Human bodies come with well-ordered defence systems against annexing pathogens and cancerous cells. Humoral defences entail (PAMP)receptors, antibacterial polypeptides, supplement systems, and most importantly, antibodies. Sterile polypeptides consist of certain enzymes that take up bacterial cell crusts and rinds. PAMP-receptors happen to identify molecules found on specific groups of pathogens. They, in turn, dissimilate pathogens for the counterpart system. The supplement system is a torrent of proteolytic enzymes that crop up anaphylactic peptides and membrane openings that undergo lysis and the cells get streaked as foreign either by antibodies or by PAMP-receptors.

Antibodies are nothing but proteins that explicitly distinguish foreign materials and make a foreign cell more susceptible to phagocytosis along with boosting up the cellular resistance system. They are fabricated from certain building blocks that are arbitrarily joined together and put through hypermutation. This is how an almost inestimable variation of antibodies can be formed from a finite number of genes. Procuring explicit antibodies cells for two weeks; in the meantime, the body becomes reliant on innate immunity. Once an antibody reaction has been parched on, the immune system dredges up that pathogen for the rest of our life. Simulated exposure to antigens from immunization can safeguard one from infections and can act as one of the most efficient weapons against contagious diseases.

Nowadays, building up immunity should become a pivotal concern for one and all. We live in an era when we hardly get any time to follow hale and hearty routines. And, when we are not in a proper dietary habit, we also don't get the required portion of nutrition. Inadequate sleep and debauching on unhealthy, junk food do have an appalling impact on our immunity and with such indecorous habit on board, the system becomes frail and feeble. A body with weakened immunity becomes highly prone to attack from bacteria and that's how one is caught with viral flu, common cold, and flu. And, if not taken proper precaution, one could get affected with serious illnesses like meningitis and pneumonia.

These immunoproteins comprehend to the nourishment of specific nutrients that the body requires to protect itself from microbial round. They also trump up for the nutritive shortage of our everyday life. These are framed with safe components, especially chosen to contend with the issue of weak immunity.

Protein is highly needed to restore immunity cells. It is often referred as the building block of life. Human body needs protein to function in the right manner. Without adequate proteins, the body will not be able to mend up bruised immunity cells or formulate new ones. Also, one needs protein for the restoration of muscles, tissues, and cells. They not only aid in the proper movement of muscles, but also tend to offer the much required support to the organs. If enough protein is not consumed, one's body will become feeble and weedy, their immunity will not work, and eventually, they will end up losing energy.

Carbohydrates are also required to escalate one's endurance. One might have such fallacy in mind that carbohydrates can make them fat, but in reality, they tend to serve an array of important functions. When they help to beef up physical endurance, they can also even out the natural defence system of one's body. One does need this essential nutrient to provide one's body with the required verve and strength to put on all the daily functions.

Minerals tend to evade infections and allergies too. Certain minerals like magnesium, calcium, sodium, zinc, and iron are highly needed for the body functions to operate in an orderly manner. They are mainly essential for heightening and improving one's immune response. At the same time, minerals are also needed for heartbeat regulation, creation of enzyme, muscle relaxations etc.

According to Allied Market Research, the global immunoprotein diagnostic testing market is anticipated to register a significant CAGR from 2020 to 2027 . The growth is mainly driven by surge in occurrence of contagious and chronic ailments, rise in demand for prompt diagnostic services, and increase in elderly population. Moreover, top-end technological advancements in immunodiagnostic equipment and emergence of unique automated systems have supplemented the market growth yet more. On the other hand, highly convoluted regulatory framework for the approbation of various immunoprotein diagnostic tests is expected to curtail the growth to some extent. Nevertheless, constant development in the condition-specific tests and analyzes and growing inclination toward fast diagnosis across the world have almost toned down the impeding factor and paved the way for lucrative opportunities in the industry.

Here, it's worth mentioning that the arrival of Covid-19 pandemic presented a severe challenge before an array of industry verticals and certain share of the healthcare sector was also not an exception in this 
regard. The immunoprotein diagnostic testing market was also affected to some point, as sporadic and irregular supply chain events in fabricating and dispensing diagnostic kits acted as a barrier against the healthy growth of the market. Furthermore, several trade restrictions and scarcity of human resources also butted in on the hassle-free distribution of these testing equipment to the consumers.

Still, this toxic impact is gradually being compensated by the rising demand of these test kits for COVID-19 detection. At the same time, organizations dealing with pharmaceutical equipment are also granted emergency-use sanction for diagnostic assays in order to grapple with the current pandemic situation. This, in turn, has heightened the demand for diagnostic testing in many countries, thus boosting the growth of the immunoprotein diagnostic testing market in more than one way. Briefly put, the impact of the pandemic is projected to remain positive for the frontrunners in the industry, due to the growing number of COVID-19 cases and the ongoing research \& development activities regarding the prospective use of immunoproteins for instigating antibodies against the SARS-CoV-2 virus.

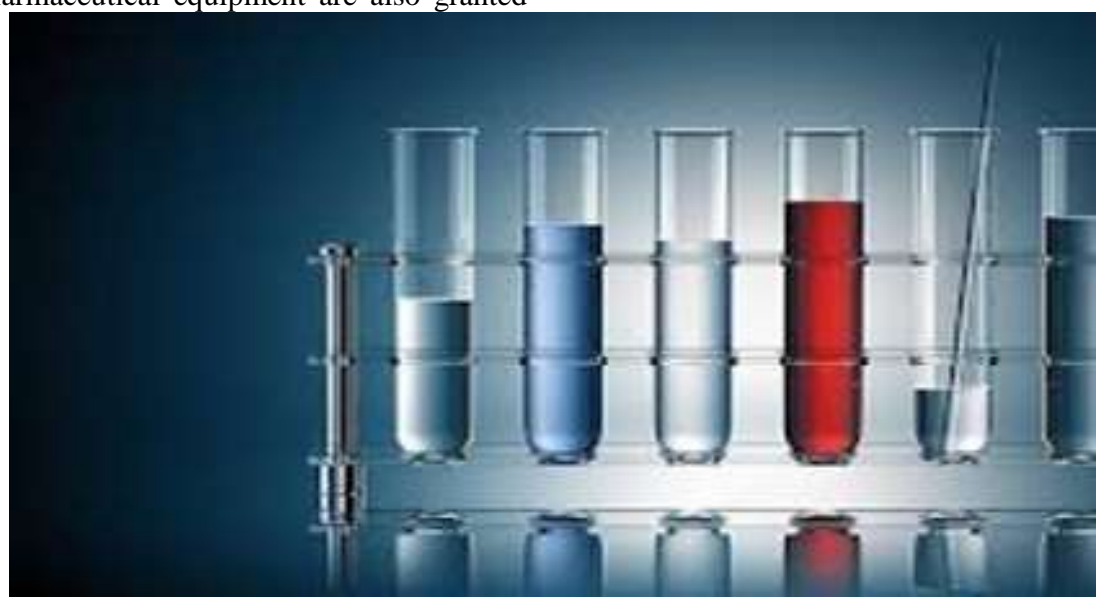

This work is licensed under Creative Commons Attribution 4.0 License

\section{To Submit Your Article Click Here: Submit Manuscript}

DOI: $10.31579 / 2690-8794 / 080$
Ready to submit your research? Choose Auctores and benefit from:

* fast, convenient online submission

* rigorous peer review by experienced research in your field

* rapid publication on acceptance

* authors retain copyrights

* unique DOI for all articles

* immediate, unrestricted online access

At Auctores, research is always in progress.

Learn more www.auctoresonline.org/journals/clinical-medical-reviewsand-reports 